Conference Proceedings Paper

\title{
Effectiveness of Two Different Hydrophobic Topcoats for Increasing of Durability of Exterior Coating Systems on Oak Wood
}

\author{
Miloš Pánek, Ondřej Dvořák, Eliška Oberhofnerová *, Kristýna Šimůnková \\ and Aleš Zeidler \\ Department of Wood Processing and Biomaterials; Faculty of Forestry and Wood Sciences; \\ Czech University of Life Sciences in Prague; Kamýcká 129, 16500 Prague, Czech Republic; \\ panekmilos@fld.czu.cz (M.P.); dvorak18@fld.czu.cz (O.D.); oberhofnerova@fld.czu.cz (E.O.); \\ simunkovak@fld.czu.cz (K.Š.); zeidler@fld.czu.cz (A.Z.) \\ * Correspondence: oberhofnerova@fld.czu.cz; Tel.: +420-224-383-867
}

Received: 10 February 2019; Accepted: 15 March 2019; Published: 15 March 2019

\begin{abstract}
Top hydrophobic layer can increase durability of exterior coatings on wood. Two hydrophobic topcoats-synthetics and water-based acrylate resin with wax additives were researched as top layer on twenty-four different coating systems applied on oak wood in this experiment. Artificial accelerated weathering lasted six weeks. Changes of color, gloss, surface wetting were evaluated, and microscopic analyses of coated surfaces were done. The results have shown that top hydrophobic layer increases durability of tested coating systems in most cases. However, the effectiveness of the two researched hydrophobic topcoats was different depending on the specific tested coating systems.
\end{abstract}

Keywords: artificial weathering; durability; exterior coatings; hydrophobic topcoat; oak wood

\section{Introduction}

Wood is in outdoor applications subjected to degradation caused by abiotic and biotic factors [1]. Even without ground contact (class 3 by EN 350 [2]), the rapid degradation of surface layers caused by the interaction of water and solar radiation takes place [3]. Wood with lower natural durability is more susceptible to biological attack - mainly by wood destroying fungi and insect [1]. Often used option of wood protection against above-mentioned damage is the use of coating systems $[4,5]$.

The other possibility is also the use of hydrophobic coatings or wood hydrophobization itself [6-8]. The hydrophobic compounds generally decrease the amount of absorbed water which leads to decrease of wood swelling and shrinkage [6,9]. This limitation of dimensional changes leads to slower degradation process outdoors [10]. Additionally, hydrophobic coatings prevent wet conditions creating a very favorable environment for the growth of various wood degrading biological organisms (e.g., diverse fungi, bacteria, and insects) [9]. Common surface hydrophobization methods include, but are not limited to, treatments based on silicone [11-13] and surface impregnation with various waxes, oils, or acrylate coatings [9,14-16]. In other studies, wood surfaces were also treated by heat [17] or plasma [18] to improve water resistance. Through the introduction of nanotechnology, the different hydrophobic treatments are developing at a rapid pace [6,19]. Nanoparticles based on titanium dioxide [20], silica nanoparticles [21] or zinc oxide were applied as hydrophobic treatments to wood. Nevertheless, many of these approaches, especially the nanoparticles impact can be discussed [22], have a negative environmental impact and cause damage to the ecosystem because of the possibility for hazardous chemicals to leak from the surface [6]. 
Hydrophobic coatings themselves are not usually able to ensure sufficient protection of wood surfaces against weathering-they do not protect the underlying wood against solar radiation causing decomposition of lignin and extractives and their leaching connected with visual color changes $[7,8,23]$. Another use of hydrophobic coatings is their application as topcoat to prevent the synergistic action of solar radiation and water [24,25]. In previous studies [1-28], the efficiency of top hydrophobic coating to prolong the overall service life of coating system applied on Norway spruce and Black locust wood was proved.

It would be preferable to use oak wood (Quercus patreae, L.) in the outdoor applications as an available wood with higher durability against biotic damage (EN 350 [2].). Without surface protection, however, it rapidly changes its color in exterior [29] and leaching of extractives occurs, which can aesthetically damage other parts of construction (balcony, façade, terrace etc.). Due to complex morphological structure of oak wood with opened vessels and specific tannins content [30] is the service life of coating systems on oak wood outdoors insufficient [31]. Hydrophobic layer applied as separate coating was characterized by the lower efficiency than multilayered oil-based coating system based [8]. From these reasons, it is necessary to find a long-lasting coating system on this wood in outdoor applications.

The objective of this study is to evaluate the efficiency of transparent and semi-transparent coating systems applied on oak wood and possible enhancement of their durability by application of hydrophobic layers. The performance of different coating systems is evaluated by measuring color, gloss and surface wettability changes during artificial weathering and by confocal laser scanning microscopy.

\section{Materials and Methods}

\subsection{Wood Material}

The experiment was conducted using oak wood (Qercus patreae, L.) with mean density of $\mathrm{Q}_{0}=705 \mathrm{~kg} / \mathrm{m}^{3}$ harvested in the Czech Republic. The samples in dimensions of $40 \times 20 \times 150 \mathrm{~mm}^{3}(T \times R \times L)$ were sanded with a grain size of 120 in a longitudinal direction and visually sorted. Prepared samples were conditioned in laboratory conditions $\left(20 \pm 2{ }^{\circ} \mathrm{C}\right.$ and $\left.65 \% \mathrm{RH}\right)$ to achieve equilibrium moisture content of $12 \%$ before application of coatings and subsequently before each measurement.

\subsection{Coating Application}

The oak wood samples were treated with oil, acrylate, alkyd and synthetic coatings according to recommendation from producers given in Table 1 . The coated samples were subsequently treated with two different transparent top hydrophobic coatings $(b, c)$, which were applied by brush according to a recommendation from a producer, the remaining samples were left without hydrophobic treatment for a comparison (a), see Table 2. The cross ends of samples were sealed using silicon to prevent additional water uptake. The initial properties of prepared coating systems are given in Table 3.

Table 1. Specification of applied transparent and semi-transparent coatings.

\begin{tabular}{|c|c|c|c|c|c|}
\hline Sign & Specification & Polymer Base & $\begin{array}{l}\text { Transparent } x \\
\text { Pigmented }\end{array}$ & $\begin{array}{l}\text { Number } \\
\text { of Layers }\end{array}$ & $\begin{array}{l}\text { Spreading } \\
\text { Rate }\left(\mathrm{g} / \mathrm{m}^{2}\right)\end{array}$ \\
\hline OL-1 & Linseed oil & OIL & $\mathrm{T}$ & 2 & 100 \\
\hline OL-2 & $\begin{array}{l}\text { Oil water emulsion based on modified linseed } \\
\text { oil }\end{array}$ & OIL & $\mathrm{T}$ & 2 & 100 \\
\hline OL-3 & $\begin{array}{l}\text { Based on vegetable oils and fatty acids, with } \\
\text { carnauba and candelilla waxes, natural resins, } \\
\text { essential oils }\end{array}$ & OIL & $\mathrm{T}$ & 2 & 80 \\
\hline OL-4 & $\begin{array}{l}\text { Water-based wood oil with fungicides (BIT and } \\
\text { IPBC) }\end{array}$ & OIL & $\mathrm{T}$ & 2 & 80 \\
\hline OL-5 & $\begin{array}{l}\text { Natural oils (linseed, sunflower, rapeseed) with } \\
\text { metal oxides pigments and titanium dioxide }\end{array}$ & OIL & $\mathrm{T}$ & 2 & 100 \\
\hline
\end{tabular}




\begin{tabular}{|c|c|c|c|c|c|}
\hline OL-6 & $\begin{array}{l}\text { Oil with nano UV-absorbers and plant essential } \\
\text { oils }\end{array}$ & OIL & $\mathrm{T}$ & 2 & 80 \\
\hline OL-7 & Oil with fungicides (BIT and IPBC) & OIL & $\mathrm{T}$ & 2 & 80 \\
\hline OL-8 & $\begin{array}{l}\text { Thin oil-based layer with micronized pigments } \\
\left.\left(\mathrm{TiO}_{2}\right) \text { and fungicides (propiconazole }<1 \%\right)\end{array}$ & OIL & S & 2 & 100 \\
\hline OL-9 & $\begin{array}{l}\text { Thin oil-based layer slightly pigmented with } \\
\mathrm{Fe}_{2} \mathrm{O}_{3} \text { and fungicides (propiconazole }<1 \% \text { ) }\end{array}$ & OIL & $\mathrm{S}$ & 2 & 100 \\
\hline $\begin{array}{l}\text { OL- } \\
10\end{array}$ & $\begin{array}{l}\text { Penetrating oil-based with pigments and } \\
\text { terpineol }(<2.5 \%)\end{array}$ & OIL & $S$ & 2 & 100 \\
\hline $\begin{array}{l}\text { AC- } \\
1\end{array}$ & $\begin{array}{l}\text { Acrylate copolymer water dispersion, } \\
\text { propiconazole and IPBC }+ \text { Modified linseed oil }\end{array}$ & $\begin{array}{l}\text { ACRYLATE + } \\
\text { OIL }\end{array}$ & $\mathrm{T}$ & $1+2$ & $100+100$ \\
\hline $\begin{array}{l}\text { AC- } \\
2\end{array}$ & $\begin{array}{l}\text { Water-based medium-solid-glaze with UV } \\
\text { blocker, biocides-free fungicides }\end{array}$ & ACRYLATE & $\mathrm{T}$ & 2 & 100 \\
\hline $\begin{array}{l}\text { AC- } \\
3\end{array}$ & $\begin{array}{l}\text { Water-based copolymer dispersion with } \\
\text { hydrophobic waxes, UV filters and metal oxides }\end{array}$ & ACRYLATE & $\mathrm{T}$ & 2 & 100 \\
\hline AL-1 & $\begin{array}{l}\text { Alkyd water-based lasur with fungicides (IPBC } \\
0.4 \% \text { ) and UV-stabilizers (benzotriazoles }<0.8 \% \text { ) }\end{array}$ & ALKYD & $\mathrm{T}$ & 2 & 100 \\
\hline AL-2 & $\begin{array}{l}\text { Water-based emulsion of modified linseed oil } \\
\text { with biocides and metal oxides }+ \text { Alkyd water- } \\
\text { based lasur with fungicides (IPBC } 0.4 \% \text { ) and } \\
\text { UV-stabilizers (benzotriazoles }<0.8 \% \text { ) }\end{array}$ & OIL + ALKYD & $\mathrm{T}$ & $1+1$ & $100+100$ \\
\hline AL-3 & Alkyd resins with UV protective pigments & ALKYD & $\mathrm{S}$ & 2 & 100 \\
\hline AL-4 & $\begin{array}{l}\text { Alkyd medium layer lasur based on solvents } \\
\text { with UV absorbers and fungicides }\end{array}$ & ALKYD & $S$ & 2 & 100 \\
\hline AL-5 & $\begin{array}{l}\text { Thin film lasur based on natural oils and alkyd } \\
\text { resins }\end{array}$ & ALKYD & $S$ & 2 & 100 \\
\hline SL-1 & $\begin{array}{l}\text { Hybrid polyurethane-alkyd synthetic yacht } \\
\text { varnish with butanone oxime as additive }\end{array}$ & $\begin{array}{l}\text { SYNTHETIC } \\
\text { LASUR }\end{array}$ & $\mathrm{T}$ & 3 & 100 \\
\hline SL-2 & $\begin{array}{l}\text { Synthetic lasur with fungicides (IPBC } 0.3 \% \text { ) and } \\
\text { UV-stabilizers }\end{array}$ & $\begin{array}{l}\text { SYNTHETIC } \\
\text { LASUR }\end{array}$ & $\mathrm{T}$ & 2 & 100 \\
\hline SL-3 & $\begin{array}{l}\text { Thin film synthetic lasur based on solvents with } \\
\text { UV protection }\end{array}$ & $\begin{array}{l}\text { SYNTHETIC } \\
\text { LASUR }\end{array}$ & $S$ & 2 & 100 \\
\hline SL-4 & $\begin{array}{l}\text { Impregnation biocide coating protective against } \\
\text { basidiomycetes + Thin film synthetic lasur based } \\
\text { on solvents with UV protection }\end{array}$ & $\begin{array}{l}\text { SYNTHETIC } \\
\text { LASUR }\end{array}$ & $S$ & $1+2$ & $100+100$ \\
\hline SL-5 & $\begin{array}{l}\text { Synthetic solvent-based lasur without aromatics } \\
\text { and with fungicides }(0.3 \% \text { IPBC) }\end{array}$ & $\begin{array}{l}\text { SYNTHETIC } \\
\text { LASUR }\end{array}$ & $S$ & 2 & 100 \\
\hline SL-6 & $\begin{array}{l}\text { Synthetic solvent-based lasur without aromatics } \\
\text { and with fungicides ( } 0.3 \% \text { IPBC) }+ \text { Synthetic } \\
\text { lasur with fungicides (IPBC 0.3\%) and UV- } \\
\text { stabilizers }\end{array}$ & $\begin{array}{l}\text { SYNTHETIC } \\
\text { LASUR }\end{array}$ & $S$ & $1+1$ & $100+100$ \\
\hline
\end{tabular}

Note: SL-2 was both tested as a top hydrophobic layer (b, see Table 2) and also as coating system.

Table 2. Specification of applied hydrophobic topcoats.

\begin{tabular}{cccccc}
\hline Sign & Topcoat Specification & Polymer Base & $\begin{array}{c}\text { Transparent } \times \\
\text { Semi-Transparent }\end{array}$ & $\begin{array}{c}\text { Number of } \\
\text { Layers }\end{array}$ & $\begin{array}{c}\text { Spreading } \\
\text { Rate }\left(\mathrm{g} / \mathbf{m}^{2}\right)\end{array}$ \\
\hline $\mathrm{a}$ & Without hydrophobic treatment & - & - & - & - \\
$\mathrm{b}$ & $\begin{array}{c}\text { Synthetic lasur with fungicides (IPBC } \\
0.3 \% \text { ) and UV-stabilizers }\end{array}$ & $\begin{array}{c}\text { SYNTHETIC } \\
\text { LASUR }\end{array}$ & $T$ & 1 & 100 \\
\hline c & $\begin{array}{c}\text { Colorless water-based protection } \\
\text { with hydrophobic polymers, } 0.1 \%- \\
0.2 \% \text { IPBC }\end{array}$ & ACRYLATE & $T$ & 1 & 100 \\
\hline
\end{tabular}

Table 3. Mean values of initial color $\left(L^{*}, a^{*}, b^{*}\right.$, see 2.4.), gloss (see Section 2.5) and surface wettability (see Section 2.6.) of applied coating systems on oak wood.

\begin{tabular}{|c|c|c|c|c|c|c|c|c|c|c|c|c|c|c|c|}
\hline \multirow[t]{2}{*}{ Sign } & \multicolumn{5}{|c|}{ Coating without Hydrophobic Topcoat (a) } & \multicolumn{5}{|c|}{ Hydrophobic Synthetic Topcoat (b) } & \multicolumn{5}{|c|}{$\begin{array}{c}\text { Hydrophobic Water-Solvent } \\
\text { Topcoat (c) }\end{array}$} \\
\hline & $L 0^{*}$ & $a 0^{*}$ & $b_{0}^{*}$ & $G_{0}^{*}$ & $\mathrm{CA}_{0}{ }^{*}$ & $L_{0}^{*}$ & $a_{0}^{*}$ & $b_{0}^{*}$ & $G_{0}^{*}$ & $\mathrm{CA}_{0}{ }^{*}$ & $L_{0}^{*}$ & $a_{0}^{*}$ & $b_{0}^{*}$ & $G_{0}^{*}$ & $\mathrm{CA}_{0}{ }^{*}$ \\
\hline OL-1 & 51.7 & 14.6 & 29.6 & 31.1 & 102.3 & 57.6 & 12.2 & 31.1 & 24.3 & 109.9 & 59.0 & 11.0 & 30.8 & 44.8 & 99.3 \\
\hline OL-2 & 49.6 & 11.4 & 26.6 & 2.5 & 99.5 & 58.6 & 9.8 & 28.7 & 5.2 & 111.5 & 60.5 & 8.6 & 25.5 & 4.3 & 97.1 \\
\hline OL-3 & 58.1 & 11.8 & 29.3 & 7.0 & 107.9 & 58.2 & 11.4 & 29.3 & 4.1 & 111.5 & 57.0 & 10.4 & 28.4 & 23.7 & 107.0 \\
\hline OL-4 & 54.7 & 12.6 & 29.1 & 1.8 & 116.2 & 55.6 & 10.7 & 29.0 & 3.6 & 112.8 & 61.5 & 10.2 & 28.5 & 3.5 & 99.4 \\
\hline
\end{tabular}




\begin{tabular}{lccccccccccccccc}
\hline OL-5 & 50.4 & 13.2 & 30.4 & 4.3 & 101.3 & 47.6 & 14.4 & 30.2 & 7.1 & 111.8 & 52.0 & 13.8 & 33.1 & 17.5 & 96.7 \\
OL-6 & 63.2 & 9.0 & 20.6 & 19.6 & 99.9 & 60.5 & 8.9 & 18.4 & 24.4 & 110.0 & 57.1 & 8.7 & 18.8 & 18.9 & 97.6 \\
OL-7 & 54.7 & 12.8 & 30.0 & 1.5 & 120.0 & 54.7 & 13.2 & 30.9 & 4.1 & 112.9 & 53.4 & 12.7 & 29.1 & 6.9 & 104.1 \\
OL-8 & 58.7 & 8.6 & 16.9 & 9.6 & 103.9 & 60.8 & 8.3 & 19.7 & 13.6 & 106.7 & 55.7 & 8.4 & 16.7 & 17.7 & 88.4 \\
OL-9 & 43.6 & 14.5 & 24.7 & 12.7 & 102.9 & 44.6 & 14.2 & 26.9 & 13.3 & 106.7 & 52.3 & 14.6 & 35.3 & 29.2 & 92.9 \\
OL-10 & 48.7 & 13.3 & 27.1 & 4.3 & 100.8 & 55.8 & 11.5 & 29.9 & 8.5 & 106.6 & 56.3 & 11.9 & 31.0 & 5.1 & 96.7 \\
AC-1 & 55.6 & 8.6 & 22.9 & 4.1 & 114.3 & 52.2 & 9.0 & 22.7 & 5.7 & 96.1 & 50.2 & 8.3 & 20.5 & 4.1 & 94.0 \\
AC-2 & 65.3 & 6.1 & 22.5 & 12.1 & 90.9 & 67.8 & 6.7 & 26.0 & 9.9 & 116.8 & 61.0 & 6.5 & 22.0 & 18.0 & 84.7 \\
AC-3 & 49.8 & 10.0 & 27.5 & 9.7 & 90.9 & 53.5 & 10.7 & 30.6 & 5.8 & 108.7 & 51.8 & 10.1 & 28.9 & 13.4 & 84.7 \\
AL-1 & 58.4 & 9.7 & 25.9 & 4.8 & 100.0 & 50.5 & 10.0 & 24.8 & 11.8 & 109.5 & 50.8 & 10.5 & 25.4 & 11.5 & 103.1 \\
AL-2 & 49.4 & 11.5 & 26.7 & 4.6 & 103.1 & 52.4 & 11.8 & 29.6 & 7.8 & 111.3 & 53.7 & 11.2 & 29.5 & 8.3 & 103.1 \\
AL-3 & 51.8 & 20.6 & 39.8 & 9.2 & 90.4 & 49.5 & 21.0 & 38.9 & 21.5 & 105.9 & 50.2 & 18.6 & 38.4 & 28.4 & 89.4 \\
AL-4 & 52.6 & 18.1 & 36.2 & 7.0 & 98.6 & 55.6 & 17.8 & 40.9 & 18.3 & 112.8 & 50.5 & 17.1 & 34.5 & 26.4 & 92.4 \\
AL-5 & 55.1 & 13.8 & 35.0 & 4.5 & 110.2 & 57.7 & 16.5 & 40.7 & 5.1 & 116.0 & 54.3 & 17.7 & 40.3 & 4.2 & 103.0 \\
SL-1 & 55.4 & 11.3 & 28.0 & 25.9 & 103.1 & 56.2 & 12.0 & 30.5 & 20.7 & 116.7 & 53.9 & 12.4 & 29.3 & 19.2 & 90.5 \\
SL-2 & 58.0 & 9.7 & 28.3 & 9.6 & 106.8 & 60.7 & 9.6 & 29.7 & 13.0 & 110.8 & 59.6 & 10.9 & 30.4 & 13.1 & 95.5 \\
SL-3 & 50.6 & 17.2 & 36.0 & 9.2 & 98.6 & 47.6 & 15.4 & 32.2 & 12.1 & 111.8 & 50.7 & 17.0 & 36.1 & 12.5 & 92.1 \\
SL-4 & 48.3 & 14.7 & 30.1 & 3.4 & 105.2 & 51.7 & 15.6 & 34.1 & 8.4 & 88.7 & 46.4 & 14.7 & 30.0 & 9.4 & 109.6 \\
SL-5 & 52.2 & 14.3 & 34.8 & 16.4 & 104.4 & 46.4 & 13.9 & 28.5 & 11.1 & 110.8 & 50.4 & 14.2 & 32.4 & 22.8 & 94.7 \\
SL-6 & 44.8 & 13.6 & 27.0 & 13.5 & 111.4 & 46.2 & 15.4 & 28.7 & 15.0 & 109.0 & 46.7 & 14.2 & 29.0 & 14.6 & 95.4 \\
\hline
\end{tabular}

\subsection{Artificial Weathering (AW)}

Artificial weathering was performed in a UV-chamber QUV (Q-Lab, Cleveland, OH, USA) on the basis of modified EN 927-6 [32] with the test parameters given in Table 4. During the week cycle of irradiation and spraying, the samples were transferred to a conditioning chamber Discovery My DM340 (ACS, Massa Martana, Italy) and exposed to three two-hour cycles of temperature changes from -25 to $+80{ }^{\circ} \mathrm{C}$ (with $25 \% \mathrm{RH}$ ). The total weathering time consisted of 6 cycles $-1008 \mathrm{~h}$ of weathering in UV chamber and $36 \mathrm{~h}$ of temperature cycling. The alternation of UV radiation, spray, and low temperature cycles, which leads to more accurate simulation of exterior conditions in Europe, was also used in a study by Van den Bulcke [33] and Pánek [8].

Table 4. One cycle of artificial weathering.

\begin{tabular}{|c|c|c|c|c|c|}
\hline Rank & Phase & Device & Duration & Parameters & Repetition \\
\hline 1 & Condensation & UV-chamber & $24 \mathrm{~h}$ & $\begin{array}{c}T=45 \pm 3^{\circ} \mathrm{C}, \text { Water-spray (off), UV } \\
\text { (off) }\end{array}$ & $1 \times$ \\
\hline 2 & UV Irradiance & UV-chamber & $2.5 \mathrm{~h}$ & $\begin{array}{c}T=65 \pm 3{ }^{\circ} \mathrm{C}, \text { Water-spray (off), } \mathrm{UV} \\
\text { Irradiance } 1.10 \mathrm{~W} / \mathrm{m}^{2} \text { at } 340 \mathrm{~nm}\end{array}$ & \multirow[t]{2}{*}{$48 \times$} \\
\hline \multirow{3}{*}{3} & Water-spray & UV-chamber & $0.5 \mathrm{~h}$ & $T=20 \pm 1{ }^{\circ} \mathrm{C}$, Water-spray (on), UV (off) & \\
\hline & $\begin{array}{l}\text { Temperature } \\
\text { Cycling }\end{array}$ & $\begin{array}{l}\text { Conditionin } \\
\text { g chamber }\end{array}$ & $1 \mathrm{~h}$ & $T=-25^{\circ} \mathrm{C}$ & \multirow{2}{*}{$3 \times$} \\
\hline & $\begin{array}{l}\text { Temperature } \\
\text { Cycling }\end{array}$ & $\begin{array}{l}\text { Conditionin } \\
\text { g chamber }\end{array}$ & $1 \mathrm{~h}$ & $\mathrm{~T}=+80^{\circ} \mathrm{C}(\mathrm{RH}=25 \%)$ & \\
\hline
\end{tabular}

\subsection{Color Analysis}

The color parameters [34] (CIE 1986) of the test specimens were measured after 1, 3 and 6 weeks of AW using Spectrophotometer CM-600d (Konica Minolta, Osaka, Japan). The device was set to an observation angle of $10^{\circ}, \mathrm{d} / 8$ geometry and D65 light source, and the SCI method (specular component included) was used. Six measurements per sample were carried out for each weathering time. Color changes evaluations were done in CIE $L^{*} a^{*} b^{*}$ color space on the basis of $L^{*}, a^{*}$, and $b^{*}$ color coordinates, where: $L^{*}$ is lightness from 0 (black) to 100 (white); $a^{*}$ is chromaticity coordinate + (red) or - (green); $b^{*}$ is chromaticity coordinate + (yellow) or - (blue).

The relative changes in color $\left(\Delta L^{*}, \Delta a^{*}\right.$, and $\left.\Delta b^{*}\right)$ between the weathered and the initial state were determined. According to the Euclidean distance, the total color difference $\Delta E^{*}$ (CIE 1986 [8]) was subsequently calculated using Equation (1): 


$$
\Delta E^{*}=\sqrt{\left(\Delta L^{*}\right)^{2}+\left(\Delta a^{*}\right)^{2}+\left(\Delta b^{*}\right)^{2}}
$$

\subsection{Gloss Analysis}

Gloss measurements were performed on the basis of EN ISO 2813 [35] using glossmeter MG268F2 (KSJ, Quanzhou, China). Six measurements at a $60^{\circ}$ angle per sample after 1, 3, and 6 weeks of AW were done to evaluate gloss changes.

\subsection{Surface Wettability Analysis}

The performance of different hydrophobic layers on oak wood surface wettability was investigated. The water contact angle on oak wood tangential surfaces was measured using a goniometer Krüss DSA 30E (Krüss, Hamburg, Germany). The sessile drop method was used to compare the wettability of different surface treatments during artificial weathering. Ten measurements per sample were performed after 1, 3, and 6 weeks of weathering with distilled water drops with a dosing volume of $5 \mu \mathrm{L}$. The value of contact angle was recorded in $5 \mathrm{~s}$ after drop deposition on the surface as in other studies [36-38]. The phenomena of spreading and absorption of water drops on the oak wood surface was investigated via variations of the weathering time, coating system and applied hydrophobic layer.

\subsection{Macroscopic and Microscopic Analysis}

Surfaces were regularly scanned using Canon 2520 MFP scanner with 300 DPI resolution (Canon, Tokyo, Japan) to evaluate degradation of tested coating systems. Microscopic structural changes of coatings and wood surfaces were studied using confocal laser scanning microscope Lext Ols 4100 (Olympus, Tokyo, Japan) with 108-fold magnification.

\subsection{Statistical Evaluation}

Statistical analyses were performed in MS Excel (Microsoft, Redmond, WA, USA) and Statistica (StatSoft, Palo Alto, CA, USA) using mean values, scatter plots with mean values and ANOVA (analysis of variance) with significance level $\alpha=0.05$.

\section{Results and Discussion}

The change of surface properties of tested coating systems during AW exposure was evaluated with respect to the type of polymer base (oil, acrylate, alkyd, synthetic-Table 1) and hydrophobic topcoat (acrylate and synthetic-Table 2), see Figure 1.

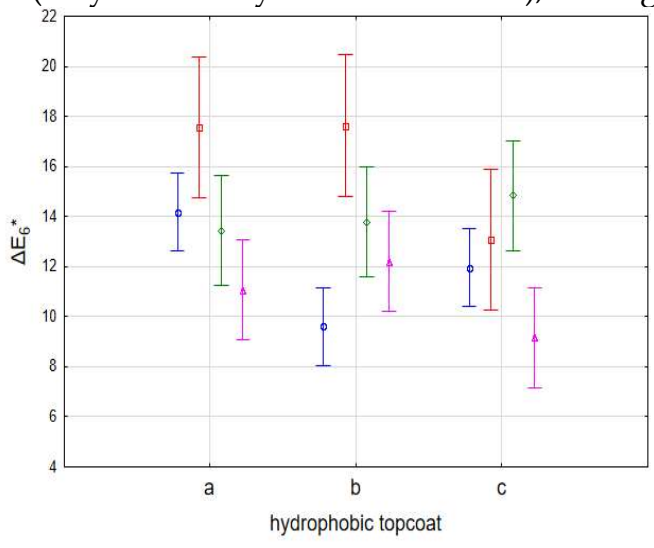

$$
\Phi \mathrm{OL}
$$

(a)

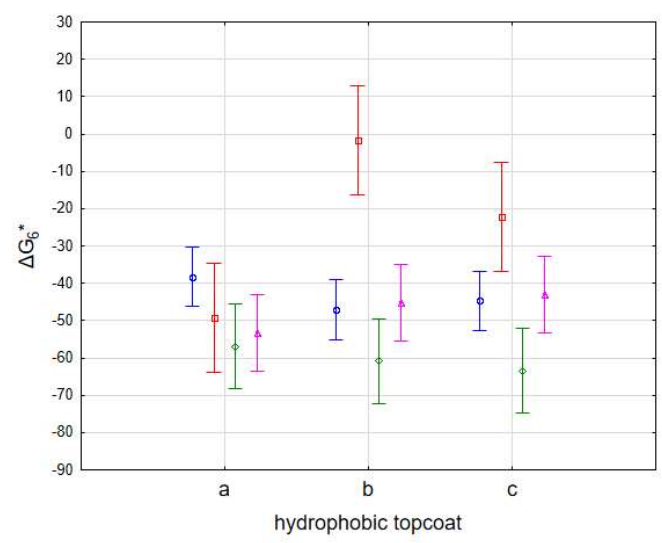

平 AL 本 SL

Figure 1. Efficiency of hydrophobic layer on the color (a) and gloss change (b) after 6 weeks of AW. 


\subsection{Color and Gloss Evaluation}

In statistical analysis the effect of polymer base type on color and gloss parameters was evaluated as statistically significant $(p=0.00)$. In contrary, the effect of hydrophobic topcoat type on color changes was evaluated as statistically insignificant $(p=0.07)$ and significant for gloss changes $(p=0.03)$. The following graphs show the values of gloss and color changes of individual coating systems with oil and acrylate polymer base (Figure 2) and alkyd and synthetic base (Figure 3). Based on the results, the lowest color and gloss changes were generally recorded for oil and synthetic coating systems (Figure 1). The color change $\Delta E^{*}<3$, which cannot be recognized by human eye [39], was after AW test observed only in the case of oil coating systems-OL-8c, Ol-6c, OL-8a and OL-10b. The decrease of gloss during AW exposure occurred almost in all tested variants of coating systems, except OL-3b, OL-4a, OL-7a, AC-2b and AC-2c.

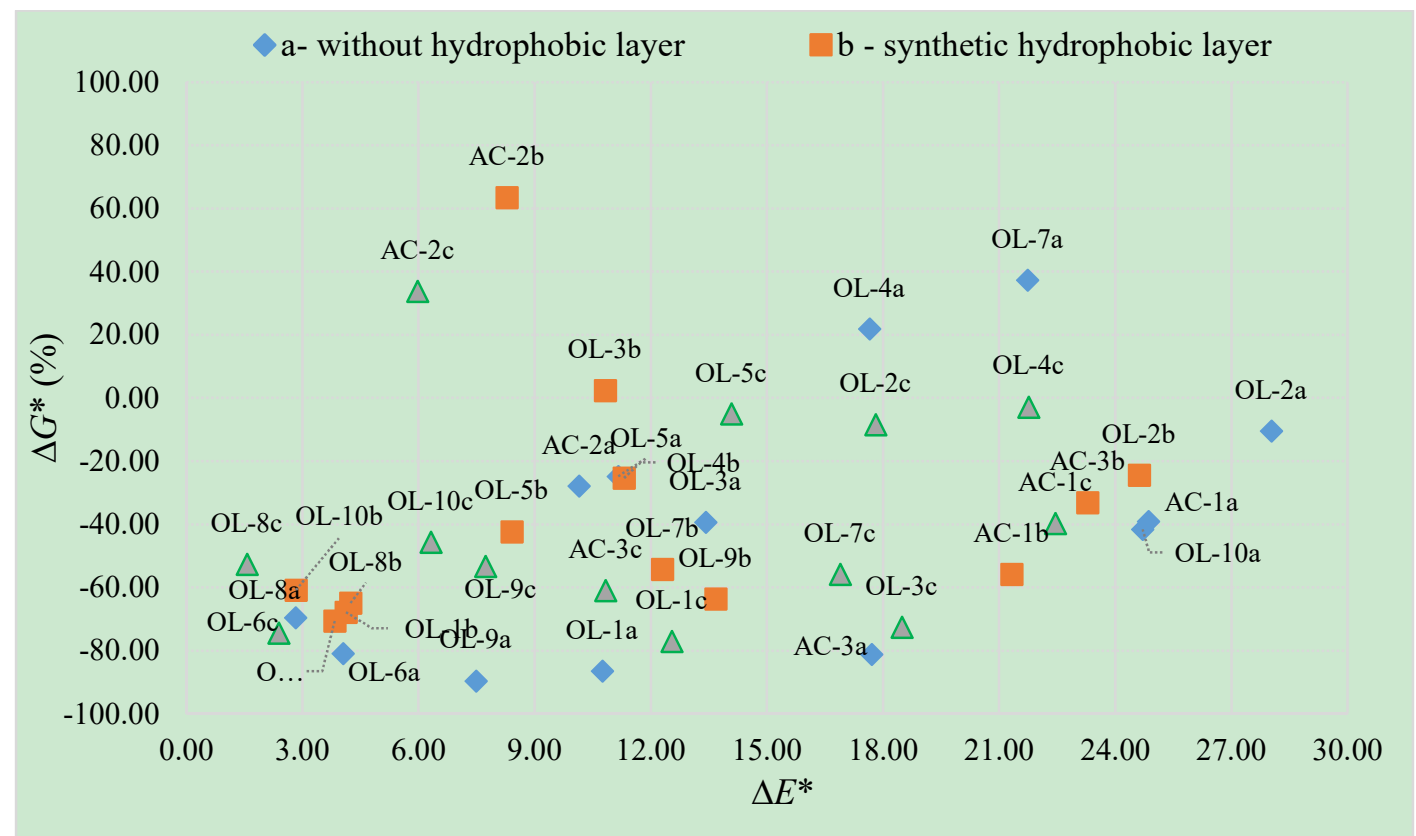

Figure 2. Gloss and color changes of oil and acrylate coating systems after 6 weeks of AW.

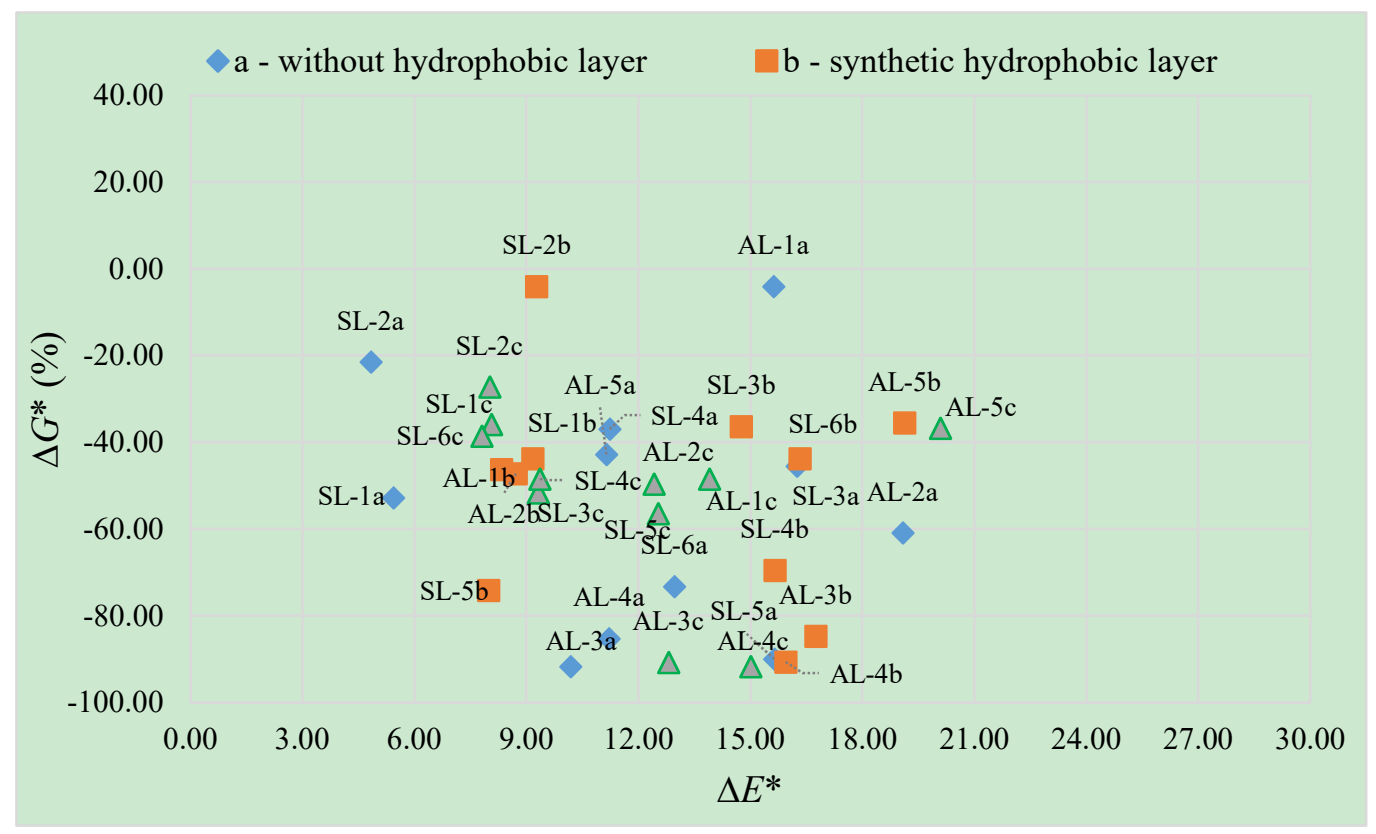

Figure 3. Gloss and color changes of alkyd and synthetic coating systems after 6 weeks of AW. 


\subsection{Surface Wettability Evaluation}

The wetting contact angle provides an overview of the functionality of hydrophobic layers during weathering (Figures 4-6). The change of contact angle of tested coating systems during AW exposure was statistically evaluated with respect to the type of polymer base (oil, acrylate, alkyd, synthetic) and the use of the hydrophobic layer (without hydrophobic treatment, acrylate and synthetic treatment), see Figure 4 . Based on the results, there is a significant loss of contact angle due to AW, mainly when hydrophobic layer was not applied (Figure 4). In the case of coating systems without hydrophobic layer (a), the acrylate and synthetic coatings systems have reached the lowest contact angle values. The efficiency of hydrophobic topcoats on the surface wettability was observed for both types, but more pronounced positive effect was observed for the hydrophobic acrylate waterbased topcoat (c) in comparison with synthetic one (b).

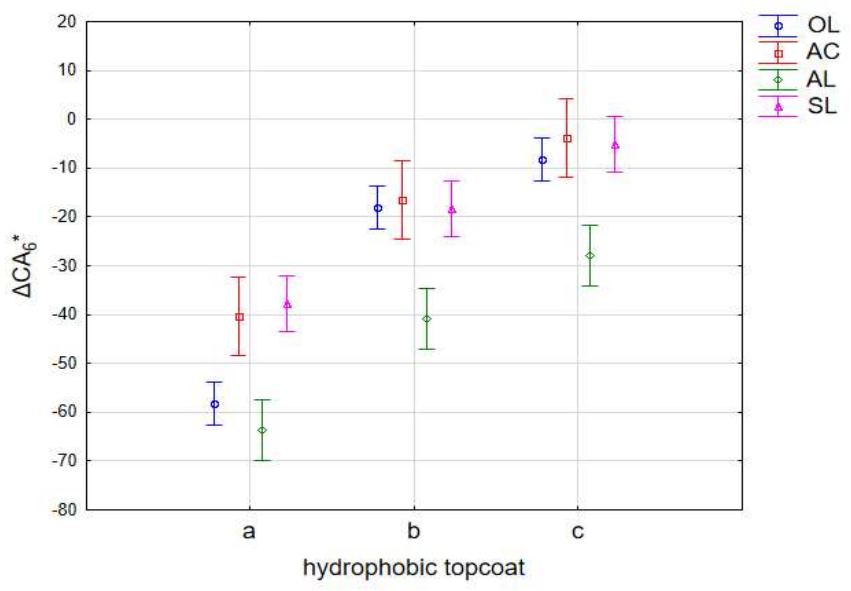

Figure 4. Efficiency of hydrophobic layer on the contact angle change after 6 weeks of AW.

In statistical analysis the effects of polymer base type and hydrophobic topcoat on contact angle values were evaluated as statistically significant $(p=0.00)$. The following graphs show the values of contact angle changes of oil and acrylate coating systems (Figure 5) and alkyd and synthetic coating systems (Figure 6). At the same time, the factor of total color change is also observed.

Only coating systems, that were not noted for decrease of the contact angle, but for slightly increase after 6 weeks of AW, were coating systems AC-2c, AD-3c, OL-8c, OL-9c, OL-10c, SL-1c a SL2c. That confirmed the results stated in Figure 4-that acrylate hydrophobic topcoat had the most positive effect on the wettability of tested surfaces. The rest of tested coating systems was noted for slightly or more pronounced decrease of contact angle values after 6 weeks of AW. Full surface wettability $(100 \%$ decrease of initial value) was determined for some coating systems without hydrophobic topcoat and alkyd coating system with synthetic hydrophobic layer AL-3b. 


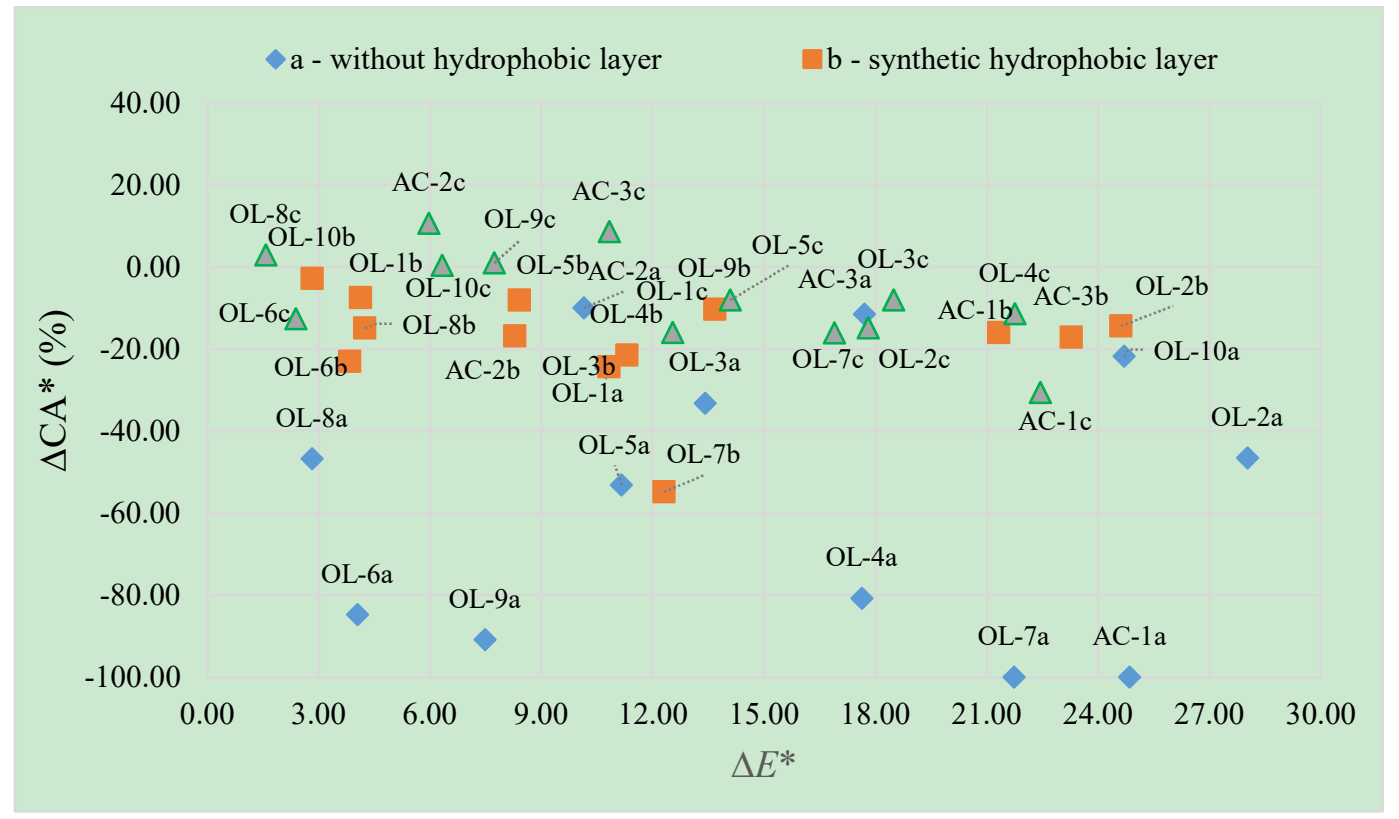

Figure 5. Contact angle change of oil and acrylate coating systems after 6 weeks of AW.

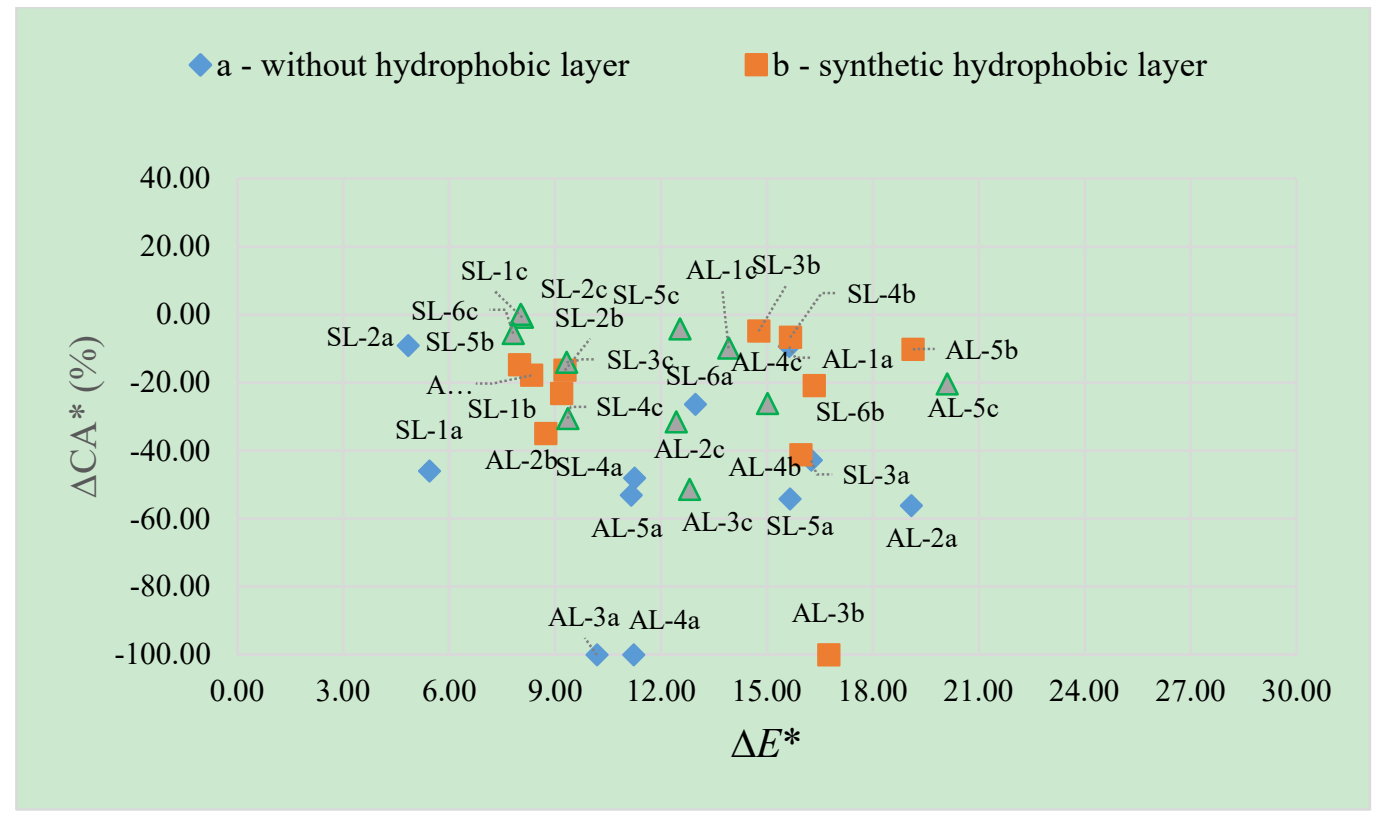

Figure 6. Contact angle change of alkyd and synthetic coating systems after 6 weeks of AW.

\subsection{Visual and Microscopic Evaluation}

Based on the results presented in Table 5 and Figure 7, it can be seen that the results of color and gloss changes (Figures 2 and 3) or changes in the contact angle (Figures 5 and 6) did not always correspond to visually observed degradation of coating systems. For example, coating systems OL$10 \mathrm{~b}$ and OL-10c were characterized by a relatively low color change (Figure 2) and minimal decrease of contact angle (Figure 5), but their overall visual degradation was quite pronounced (Table 5 and Figure 7). If the top layer of coating is degraded, but the penetrated layer remains, the significant visual changes occur, but the contact angle can be unaffected [8,40]. At the same time, it can be stated that coatings with better results of visual evaluation according to Table 5 (e.g. OL-8, OL-9, SL-3, SL6b) were characterized by a lower decrease of contact angle values $\Delta \mathrm{CA}^{*}$ and total color change $\Delta E^{*}$ (except AL-3). Some selected coating systems were for a comparison analyzed by confocal laser scanning microscopy before and after AW test (Figure 8). 
Table 5. Degradation of coating systems (based on methodology done by De Windt [41].

\begin{tabular}{cccc}
\hline Sign & $\begin{array}{c}\text { Without Hydrophobic } \\
\text { Topcoat (a) }\end{array}$ & $\begin{array}{c}\text { With Synthetic Hydrophobic } \\
\text { Topcoat (b) }\end{array}$ & $\begin{array}{c}\text { With Acrylate Hydrophobic } \\
\text { Topcoat (c) }\end{array}$ \\
\hline OL-1 & 10 & 8 & 6 \\
OL-2 & 10 & 10 & 10 \\
OL-3 & 10 & 10 & 10 \\
OL-4 & 10 & 10 & 10 \\
OL-5 & 8 & 6 & 4 \\
OL-6 & 8 & 4 & 8 \\
OL-7 & 10 & 10 & 10 \\
OL-8 & 4 & 6 & 4 \\
OL-9 & 4 & 4 & 2 \\
OL-10 & 10 & 8 & 8 \\
AC-1 & 10 & 10 & 10 \\
AC-2 & 10 & 8 & 6 \\
AC-3 & 8 & 8 & 6 \\
AL-1 & 10 & 8 & 8 \\
AL-2 & 10 & 8 & 4 \\
AL-3 & 2 & 4 & 6 \\
AL-4 & 6 & 6 & 4 \\
AL-5 & 8 & 8 & 6 \\
SL-1 & 8 & 6 & 8 \\
SL-2 & 10 & 10 & 6 \\
SL-3 & 4 & 4 & 6 \\
SL-4 & 8 & 6 & 2 \\
SL-5 & 6 & 6 & 8 \\
SL-6 & 6 & 2 & small \\
\hline
\end{tabular}

Note: The evaluation was based on the level of degradation: i.e., $0=$ none; $2=$ small aesthetical changes; 4 = mild (easy to retreat); 6 = moderate (maintainable); $8=$ striking (maintenance is difficult); $10=$ advanced (maintenance coat cannot restore the defects). De Windt [41].

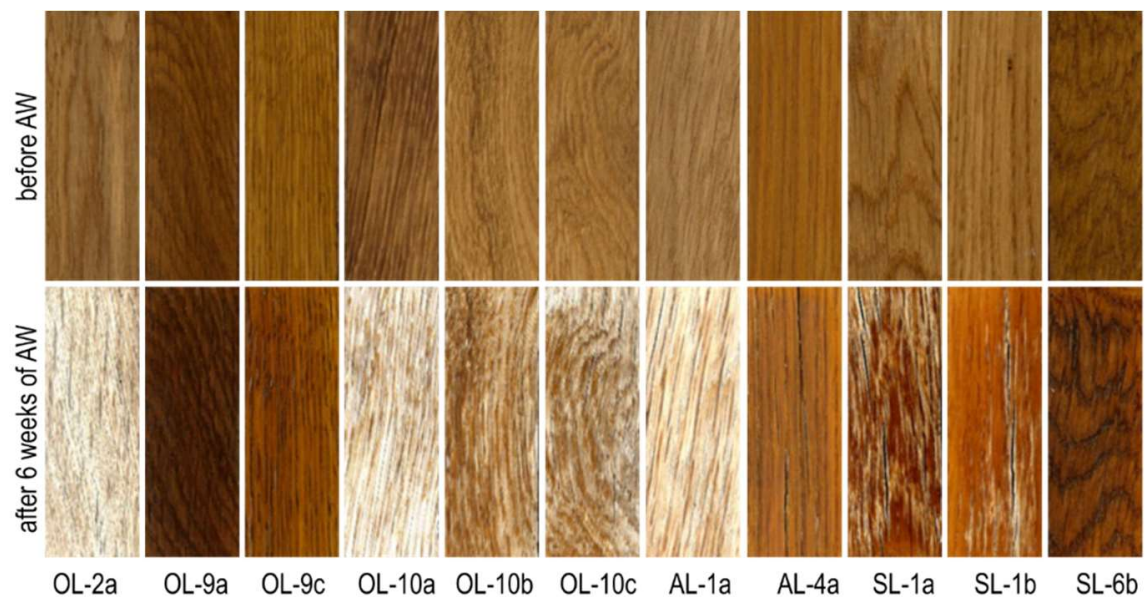

Figure 7. Visual changes of selected tested coating systems on oak wood. OL-2a: the same degradation was observed using hydrophobic treatments b and c; OL-9: positive effect of hydrophobic treatment (c) on color stability of AW samples; OL-10: partly positive effect of hydrophobic topcoat application b and c; AL-1: very similar degradation was observed using hydrophobic treatments b and c; AL-4: positive effect of pigment content increasing durability of alkyd coating (in comparison with transparent AL-1a); SL-1: positive effect of application of topcoat b; SL-6b: positive effect of application of topcoat $b$. 


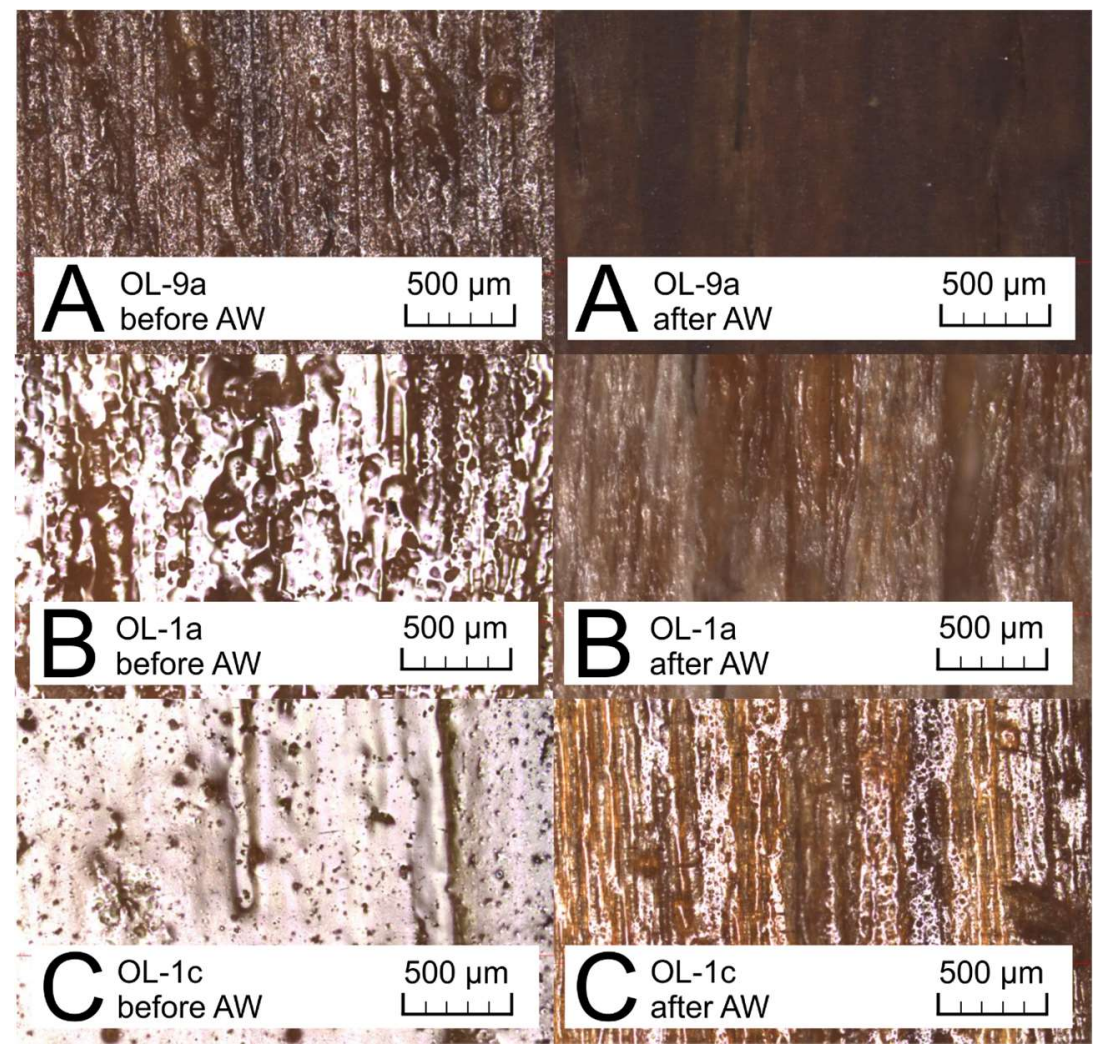

Figure 8. Microscopic changes (using Confocal Laser Scanning Microscopy) of coating surfaces. OL9a (A), OL-1a (B), OL-1c (C) and SL-6b (D) before (left) and after 6 weeks of AW (right). It is possible to see loss of gloss and color changes of OL-9a, but coating layer is not degraded (A); Positive effect of hydrophobic top coat (c) application on OL-1 is visible (B and C); Good durability of SL-6b after $\mathrm{AW}$ - only darkening is visible, surface is relatively unchanged. .

\subsection{Final Discussion of Results}

The results of the experiment in this work confirmed that application of the top hydrophobic layer can extend the overall durability of coating systems on oak wood as well as on other wood species $[24,1,28]$. However, it is necessary to apply a suitable hydrophobic layer to a specific coating system, because the resulting effect differs (Figures 5 and 6). The effect of a specific coating system (polymer base and additive content) on its overall service life was confirmed [41-43]. The choice of a suitable oak wood exterior coating system is crucial (Table 4). The application of the top hydrophobic layer did not significantly improve the properties of less suitable coating systems during exposure (Figures 2-8, Table 5). In the case of oil thin layer systems, the positive effect of pigments on the overall service life and color stability (OL-8 and OL-9, see Figures 2 and 5) was confirmed, which is consistent with other studies $[26,40,41]$. However, in the case of penetration pigmented oil without the top hydrophobic layer OL-10, rapid leaching of coating and loss of functionality occurred. Top hydrophobic layer on alkyd coating systems basically had no significant positive effect on the color stability and only low effect on the increase of the hydrophobicity of tested variants (AL-1 and AL5). The performance of synthetic coatings depended on a specific combination of layers. Only coating system SL-5 with acrylate hydrophobic layer (c) was characterized by improved functionality, in particular by preserving hydrophobicity after AW (Figure 6). Overall, the topcoat with hydrophobic additives in the acrylate water base (c) appear to be more appropriate for application on oak wood in comparison with synthetic topcoat (b). From all the tested coating systems, OL-8 and OL-9 oil-based coatings with the use of top hydrophobic layer, showed to be suitable for protection of oak wood in terms of color stability and hydrophobic effect as well as overall durability. However, it is necessary to expect a more pronounced reduction of gloss parameter [8] and in the case of OL-9 also color change (Figure 2). The performance of SL-3, SL-5 with hydrophobic topcoat (c) and SL-6 with 
hydrophobic topcoat (b) can be positively evaluated from the other tested coatings. On the contrary, transparent coating systems have generally not been effective, their higher vulnerability to degradation in comparison with pigmented ones has been fully manifested [5]. In some cases, their overall service life can be increased by application of top hydrophobic layer (coatings OL-1, OL-5 and 6 , SL-1), which is in the line with previous studies on spruce and black locust $[1,28]$. For the objective determination of coating systems quality after weathering, it is helpful to use the evaluation based on the combination of properties: the overall color and gloss change (Figures 2 and 3) and surface wettability (Figures 5 and 6) followed by a visual evaluation (Table 5, Figure 7).

\section{Conclusions}

Coated oak wood is relatively quickly subjected to degradation in exterior applications causing changes in color and gloss and reduced resistance to rainwater. The results of the experiments in this work confirmed that a particular selection of the coating system can both positively and negatively affect the overall service life of oak wood in exterior. The semi-transparent oil coatings were generally more stable in color and retained hydrophobicity in comparison with other variants. However, they were more prone to decrease of gloss. Subsequent application of the top hydrophobic layer can in the most cases increase the overall durability of the coating system. The topcoat with hydrophobic additives in the acrylate water base appeared to be more appropriate for application on oak wood in comparison with synthetic hydrophobic topcoat. Based on the variants tested, it can be generally recommended to apply the top hydrophobic layer on oil and partially acrylate coatings. For alkyd systems, the positive effect of additional hydrophobic layer was minimal. In the case of synthetic, the hydrophobic layer only rarely improved the evaluated properties. Although the experiment brings some positive results, oak wood exterior coating systems require further research with the aim to increase their overall durability, especially for transparent and less pigmented semi-transparent variants preserving natural color and texture of oak wood.

Author Contributions: M.P. conceived and designed the experiments; O.D., E.O., K.Š. and A.Z. performed the experiments, E.O. and M.P. analyzed the measured data, E.O. and M.P. wrote the paper.

Acknowledgments: This work was supported by the grant "Improving of coatings durability on selected kinds of wood in the exterior applications," No. TH02020873, financed by TA ČR.

Conflicts of Interest: The authors declare no conflict of interest.

\section{References}

1. Reinprecht, L. Wood Deterioration, Protection and Maintenance, 1st ed.; Wiley-Blackwell: Hoboken, NJ, USA, 2016; p. 376.

2. (EN) 350: 2016 Durability of Wood and Wood-Based Products-Testing and Classification of the Durability to Biological Agents of Wood and Wood-Based Materials; European Committee for Standardization: Brussels, Belgium, 2016.

3. Owen, J.A.; Owen, N.L.; Feist, W.C. Scanning electron microscope and infrared studies of weathering in Southern pine. J. Mol. Struct. 1993, 300, 105-114, DOI: 10.1016/0022-2860(93)87010-7.

4. Cogulet, A.; Blanchet, P.; Landry, V. The multifactorial aspect of wood weathering: A review based on a holistic approach of wood degradation protected by clear coating. BioResources 2018, 13, pp. 2116-2138. doi:10.15376/biores.13.1.

5. Evans, P.D.; Haase, J.G.; Shakri, A.; Seman, B.M.; Kiguchi, M. The search for durable exterior clear coatings for wood. Coatings 2015, 5, 830-864. DOI:10.3390/coatings5040830.

6. Samyn, P.; Stanssens, D.; Paredes, A.; Becker, G. Performance of organic nanoparticle coatings for hydrophobization of hardwood surfaces. J. Coat. Technol. Res. 2014, 11, 461-471. DOI: 10.1007/s11998-0149576-9.

7. Ghosch, S.C.; Militz, H.; Mai, C. Natural weathering of scots pine (Pinus sylvestris L.) boards modified with functionalised commercial silicone emulsions. BioResources 2009, 4, 659-673.

8. Pánek, M.; Oberhofnerová, E.; Zeidler, A.; Šedivka, P. Efficacy of Hydrophobic Coatings in Protecting Oak Wood Surfaces during Accelerated Weathering. Coatings 2017, 7(10), 172. DOI: 10.3390/coatings7100172. 
9. Lozhechnikova, A.; Vahtikari, K.; Hughes, M.; Österberg, M. Toward energy efficiency through an optimized use of wood: The development of natural hydrophobic coatings that retain moisture-buffering ability. Energy Build. 2015, 105, 37-42. DOI: 10.1016/j.enbuild.2015.07.052.

10. Shupe, T.; Lebow, S.; Ring, D. Causes and control of wood decay, degradation \& stain. Pub.(Louisiana Cooperative Extension Service)-2703.[Baton Rouge, La.]: Louisiana State University Agricultural Center, 2008; p. 2703.

11. Wang, C.; Zhang, M.; Xu, Y.; Wang, S.; Liu, F.; Ma, M.; Gao, Z. One-step synthesis of unique silica particles for the fabrication of bionic and stably superhydrophobic coatings on wood surface. Adv. Powder Technol. 2014, 25, 530-535. DOI: 10.1016/j.apt.2013.08.007.

12. Liu, C.; Wang, S.; Shi, J.; Wang, C. Fabrication of superhydrophobic wood surfaces via a solutionimmersion process. Appl. Surf. Sci. 2011, 258, 761-765. DOI: 10.1016/j.apsusc.2011.08.077.

13. Sébe, G.; Brook, M.A. Hydrophobization of wood surfaces: Covalent grafting of silicone polymers. Wood Sci. Technol. 2001, 35, 269-282. DOI: 10.1007/s002260100.

14. Fredriksson, M.; Wadsö, L.; Ulvcrona, T. Moisture sorption and swelling of Norway spruce [Picea abies (L.) Karst.] impregnated with linseed oil. Wood Mater. Sci. Eng. 2010, 5, 135-142. DOI: 10.1080/17480272.2010.484102.

15. Lesar, B.; Straže, A.; Humar, M. Sorption properties of wood impregnated with aqueous solution of boric acid and montan wax emulsion. J. Appl. Polym. Sci. 2011, 120, 1337-1345. DOI: 10.1002/app.33196.

16. Humar, M.; Lesar, B. Efficacy of linseed-and tung-oil-treated wood against wood-decay fungi and water uptake. Int. Biodeter. Biodegr. 2013, 85, 223-227. DOI: 10.1016/j.ibiod.2013.07.011.

17. Gérardin, P.; Petric, M.; Petrissans, M.; Lambert, J.; Ehrhardt, J. Evolution of Wood Surface Free Energy after Heat Treatment. Polym. Degrad. Stab. 2007, 92 653-657, DOI: 10.1016/j.polymdegradstab.2007.01.016.

18. Avramidis, G.; Hauswald, E.; Lyapin, A.; Militz, H.; Viol, W.; Wolkenhauer, A. Plasma Treatment of Wood and Wood-Based Materials to Generate Hydrophilic or Hydrophobic Surface Characteristics. Wood Mater. Sci. Eng. 2009, 4, 52-60, DOI: 10.1080/17480270903281642.

19. Vlad-Cristea, M.; Riedl, B.; Blanchet, P.; Jimenez-Pique, E. Nano characterization techniques for investigating the durability of wood coatings. Eur. Polym. J. 2012, 48, 441-453. DOI: 10.1016/j.eurpolymj.2011.12.002.

20. Sun, Q.; Yu, H.; Liu, Y.; Li, J.; Lu, Y.; Hunt, J. F. Improvement of water resistance and dimensional stability of wood through titanium dioxide coating. Holzforschung 2010, 64, 757-761. DOI: 10.1515/hf.2010.114.

21. Wang, X.; Chai, Y.; Liu, J. Formation of Highly Hydrophobic Wood Surfaces Using Silica Nanoparticles Modified with Long-Chain Alkylsilane. Holzforschung 2013, 394, 97-112. DOI:10.1515/hf-2012-0153.

22. Bondarenko, O.; Juganson, K.; Ivask, A.; Kasemets, K.; Mortimer, M.; Kahru, A. Toxicity of Ag, CuO and $\mathrm{ZnO}$ nanoparticles to selected environmentally relevant test organisms and mammalian cells in vitro: A critical review. Arch. Toxicol. 2013, 87, 1181-1200. DOI: 10.1007/s00204-013-1079-4.

23. Schaller, C.; Rogez, D. New approaches in wood coating stabilization. J. Coat. Technol. Res. 2007, 4, 401-409. DOI: 10.1007/s11998-007-9049-5.

24. Turkulin, H.; Arnold, M.; Richter, K.; Strub, E.; Rajkovic, J; Mihulja, G. Hydrophobic treatment for improvement of wood surface durability. In Proceedings of 5th International Woodcoatings Congress 'Enhancing Service Life, Prague, Czech Republic, 2006; p. 20.

25. Grüll, G.; Tscherne, F.; Spitaler, I.; Forsthuber, B. Comparison of wood coating durability in natural weathering and artificial weathering using fluorescent UV-lamps and water. Eur. J. Wood Wood Prod. 2014, 72, 367-376. DOI: 10.1007/s00107-014-0791-y.

26. Pánek, M.; Reinprecht, L. Color stability and surface defects of naturally aged wood treated with transparent paints for exterior constructions. Wood Res. 2014, 59, 421-430.

27. Reinprecht, L.; Pánek, M. Effects of wood roughness, light pigments, and water repellent on the color stability of painted spruce subjected to natural and accelerated weathering. BioResources 2015, 10, 72037219.

28. Pánek, M.; Reinprecht, L. Effect of the Number of UV-Protective Coats on the Color Stability and Surface Defects of Painted Black Locust and Norway Spruce Woods Subjected to Natural Weathering, BioResources 2016, 11, 4663-4676, DOI: 11.2.4663-4676.

29. Oberhofnerová, E.; Pánek, M.; García-Cimarras, A. The effect of natural weathering on untreated wood surface. Maderas. Cienc. Tecnol. 2017, 19, 173-184. DOI: 10.4067/S0718-221X2017005000015.

30. Wagenführ, R. Dřevo-Obrazový Lexikon; GRADA Publishing: Praha, Czech Republic, 2002; p. 348. 
31. Aloui, F.; Ahajji, A.; Irmouli, Y.; George, B.; Charrier, B.; Merlin, A. Inorganic UV absorbers for the photostabilisation of wood-clear coating systems: Comparison with organic UV absorbers. Appl. Surf. Sci. 2007, 253, 3737-3745. DOI: 10.1016/j.apsusc.2006.08.029.

32. EN 927-6:2006 Paints and Varnishes. Coating Materials and Coating Systems for Exterior Wood-Part 6: Exposure of Wood Coatings to Artificial Weathering Using Fluorescent UV Lamps and Water; European Committee for Standardization: Brussels, Belgium, 2006.

33. Van den Bulcke, J.; van Acker, J.; Stevens, M. Experimental and theorethical behavior of exterior wood coatings subjected to artificial weathering. J. Coat. Technol. Res. 2008, 5, 221-231. DOI: 10.1007/s11998-0079074-4.

34. Colorimetry, 2nd ed.; Commission Internationale de l'Eclairage: Vienna, Austria, 1986; p. 74.

35. EN ISO 2813:2014 Paints and Varnishes-Determination of Gloss Value at 20 Degrees, 60 Degrees and 85 Degrees; European Committee for Standardization: Brussels, Belgium, 2014.

36. Wålinder, M.; Johansson, I. Measurement of wood wettability by the Willhelmy method. Part 1 . Contamination of probe liquids by extractives. Holzforschung 2001, 55, 21-32. DOI: 10.1515/HF.2001.005.

37. Bastani, A.; Adamopoulos, S.; Militz, H. Water uptake and wetting behaviour of furfurylated, N-methylol melamine modified and heat-treated wood. Eur. J. Wood Wood Prod. 2015, 73, 627-634. DOI: 10.1007/s00107015-0919-8.

38. Gonzalez de Cademartori, P.H.; Missio, A.L.; Dufau Mattos, B.; Gatto, D.A. Natural weathering performance of three fast-growing Eucalypt woods. Maderas Cienc. Tecnol. 2015, 17, 799-808. DOI: 10.4067/S0718-221X2015005000069.

39. Sehlstedt-Persson, M. Color responses to heat-treatment of extractives and sap from pine and spruce. In Proceedings of the 8th IUFRO International Wood Drying Conference: Improvement and Innovation in Wood Drying: A Major Issue for a Renewable Material, Brasov, Romania, 24-29 August 2003; Faculty of Wood Industry, Transilvania University of Brasov: Brasov, Romania, 2003; pp. 459-464.

40. Šimůnková, K.; Oberhofnerová, E.; Reinprecht, L.; Pánek, M.; Podlena, M.; Štěrbová, I. Durability of selected transparent coatings applied on Siberian and European larch during artificial weathering test. Coatings 2019, 9, 39. DOI:10.3390/coatings9010039.

41. De Windt, I.; Van den Bulcke, J.; Wuijtens, I.; Coppens, H.; Van Acker, J. Outdoor weathering performance parameters of exterior wood coating systems on tropical hardwood substrates. Eur. J. Wood Wood Prod. 2014, 72, 261-272. DOI: 10.1007/s00107-014-0779-7.

42. De Meier, M. Review on the durability of exterior wood coatings with reduced VOC-content. Prog. Organ. Coat. 2001, 43, 217-225, DOI: 10.1016/S0300-9440(01)00170-9.

43. Syvrikaya, H.; Hafizoglu, H.; Yasav, A.; Aydemir, D. Natural weathering of oak (Quercus petrae) and chestnut (Castanea sativa) coated with various finishes. Color Res. Appl. 2011, 36, 72-78. DOI: 10.1002/col.20581.

(C) 2019 by the authors. Licensee MDPI, Basel, Switzerland. This article is an open access article distributed under the terms and conditions of the Creative Commons Attribution (CC BY) license (http://creativecommons.org/licenses/by/4.0/). 